\title{
Flexural behaviour of reinforced lightweight concrete beam using hot water pre-treated oil palm shell coarse aggregate
}

\author{
Farah Dini Sofyani ${ }^{1, *}$, Nuraziz Handika $^{1}$, Elly Tjahjono $^{1}$, and Essy Arijoeni ${ }^{1}$ \\ ${ }^{1}$ Department of Civil Engineering, Universitas Indonesia, Depok, Indonesia
}

\begin{abstract}
Along with the increasing demand for habitation in Indonesia, the need for concrete as the most favourable housing material is escalating. Oil Palm Shell (OPS) as coarse aggregate material is a possible alternatives material in concrete mix proportions. This possible choice of material not only can fulfil the requirements of the materials, but is also capable of reducing the problem of OPS waste in Indonesia. As OPS concrete compressive strength in previous studies in laboratory is in the range of 20$23 \mathrm{MPa}$, studies on larger elements of structure become interesting. This research presents flexure behaviour of lightweight concrete beams using OPS replacing natural coarse aggregates under four-point loading application. OPS is firstly pre-treated using hot water at $50^{\circ} \mathrm{C}$ based on previous research. In this study, a series of tests was conducted on two samples of identical beam with dimension of $15 \times 25 \times 300 \mathrm{~cm}$. This size represents the typical dimension of beam used in two-storey houses in Indonesia. Mechanical response due to bending that occurs in OPS lightweight concrete beam is presented. Observation on the beam is emphasised on the pure bending area.
\end{abstract}

\section{Introduction}

Palm oil is one of the strategic commodities in the agricultural sector and is widely developed in tropical countries such as Indonesia, Malaysia, and Nigeria. Based on data from the Directorate General of Plantations, Ministry of Agriculture, the oil palm area as of 2017 is estimated to reach 12.3 million hectares (Ha), and oil palm production in 2017 to reach 7.07 tons $[1,2]$. As the largest producers and exporters of palm oil in the world, obviously, by-products of palm oil are also widely produced in Indonesia. One of the solid by-products obtained from palm oil production is in shell form, the so-called Oil Palm Shell (OPS). Oil palm shells are usually used as a fuel for burning stoves in the processing of palm oil production $[3,4]$. The greater the palm oil production, the higher the amount of palm oil waste produced; however, the ineffectiveness of waste processing has led some researchers to use palm oil shell waste, especially in the civil engineering world, as a substitute aggregate material in the concrete mixture. According to Yew et al. [5], oil palm shell can be used as coarse aggregate material (biosource alternative material).

*Corresponding author: farah.dinis@gmail.com; n.handika@eng.ui.ac.id 
Research into oil palm shells as a substitute for natural coarse aggregates in concrete with various mixtures has been performed in the Laboratory of Structural and Material, Civil Engineering Department, Universitas Indonesia. Research conducted in 2016 [4, 6-9] resulted in an effective concrete mixture using palm oil shells as a substitute for natural coarse aggregate. Several admixtures were tested to obtain the best way to mix the concrete with and without additive [6-9]. These works were performed by examining the mechanical properties of the concrete. The highest compressive strength obtained was $21.82 \mathrm{MPa}$ at 28 days of concrete age. From these previous results, it seems promising to continue the research on larger structural elements of concrete, namely reinforced concrete structure. Furthermore, recent research for pre-treatment of OPS [10] shows some possibilities to apply on a large scale of structural elements.

In this paper, the experimental works focused on the mechanical behavior of the beam using OPS concrete. Two reinforced concrete beams with the dimension of $15 \times 25 \times 300 \mathrm{~cm}$ are investigated in this study. This 2.7-meter span length beam (support to support distance) is tested under four-point loading. Vertical displacement at mid-span and for every onefourth distance is measured. In this works, results from [6-9] are used as a reference of mix design to determine the most effective concrete strength by water pre-treatment on OPS with hot water according to [10]. Interesting results are obtained from this experiment: the beam can withstand a load of 5.06 tonnes (average of two specimens). The maximum vertical displacement (service) according to Indonesian National Standard [11] of 11.25 $\mathrm{mm}(1 / 240)$ was reached at 4.6 tonnes (average of two specimens).

\section{Material characterizations}

Characteristic tests for each material were performed to obtain the properties of concrete and steel bar to obtain the material properties.

\subsection{OPS Concrete}

Table 1. Mix design of OPS Concrete [4, 6-9].

\begin{tabular}{|l|l|}
\hline W/C & $7 / 20$ \\
\hline Type of sand & $0-5 \mathrm{~mm}\left(860 \mathrm{~kg} / \mathrm{m}^{3}\right)$ \\
\hline OPS aggregates & $4.75-12.5 \mathrm{~mm}\left(273 \mathrm{~kg} / \mathrm{m}^{3}\right)$ \\
\hline Type of Cement & Portland Composite Cement $\left(500 \mathrm{~kg} / \mathrm{m}^{3}\right)$ \\
\hline
\end{tabular}

Table 2. Mechanical properties of concrete materials.

\begin{tabular}{|l|c|}
\hline \multicolumn{1}{|c|}{ Mechanical properties } & Values (MPa) \\
\hline Concrete compressive strength $^{*}$ & $22.33 \pm 0.42$ \\
\hline Concrete flexural strength $^{*}$ & $2.15 \pm 0.20$ \\
\hline Average \pm standard deviation of experimental results from 5 samples at 28 days after casting.
\end{tabular}

Table 1 describes the concrete materials used in this research. Table 2 describes the mechanical properties of concrete obtained from the three tests on the cylindrical sample with $15 \mathrm{~cm}$ of diameter and $30 \mathrm{~cm}$ of height. OPS concrete contains lightweight aggregate, and laboratory testing shows $1792 \mathrm{~kg} / \mathrm{m}^{3}$ of concrete density, which fulfills the requirement of lightweight concrete stated in the National Standard [11]. After concrete casting, RC 
beam was let harden inside a room with usual treatment to prevent the early shrinkage phenomenon. After 28 days, it was removed from the mold and exposed to ambient combinations.

\subsection{Steel bar reinforcement}

The nominal bar diameters were $6 \mathrm{~mm}$ and $13 \mathrm{~mm}$, corresponding to a cross section of $28.26 \mathrm{~mm}^{2}$ and $132.73 \mathrm{~mm}^{2}$. Tensile tests were performed according to SNI [12] in which the bars were formed leaving their core of steel bar.

Table 3. Mechanical properties of steel reinforcement bar.

\begin{tabular}{|crrrr|}
\hline \multicolumn{4}{|c|}{ Steel Reinforcement Bar } & \\
\hline Nominal diameter of steel bar & $\phi_{n}=$ & 13.00 & $\mathrm{~mm}$ \\
Yield strength $^{\ddagger}$ & $f_{y}=$ & $419.28 \pm 17.74$ & $\mathrm{MPa}$ \\
Ultimate strength $^{\ddagger}$ & $f_{u}$ & $=$ & $568.60 \pm 16.29$ & $\mathrm{MPa}$ \\
\hline
\end{tabular}

${ }^{\ddagger}$ Average \pm standard deviation value of tensile test results from four samples of reinforcement bars.

\section{Experimental series}

\subsection{Detail of experiment}

Detail and configuration of OPS RC beam dimensions and steel bar reinforcement are presented in Fig. 1. After 44 and 48 days, four-point loading tests were conducted on beam 1 and beam 2 respectively. The two beams have the depth of $25 \mathrm{~cm}$, the thickness of $15 \mathrm{~cm}$ and length of $300 \mathrm{~cm}$, which leads to an effective span equal to $270 \mathrm{~cm}$. The two beams were fabricated and designed as under reinforced beams according to the National Standard [11]. Both are the same sample with the same concrete and steel bar reinforcement configuration. The configuration of the reinforcement is as follows: $13 \mathrm{~mm}$ of the ribbed bar is used for longitudinal bar, three bars on the bottom, and two bars on the top. The spacing of the transverse reinforcement is $10 \mathrm{~cm}$ with $6 \mathrm{~mm}$ of the diameter of the plain bar. This dimension is chosen as a representation of the dimensions of the type of beam that is generally used for housing.

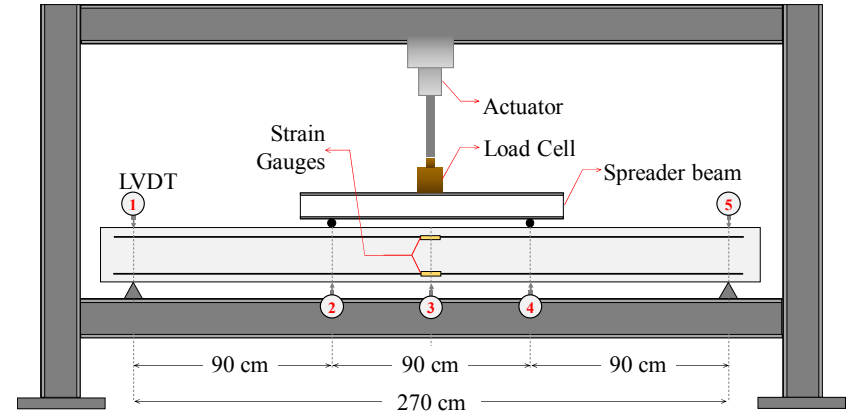

(a)

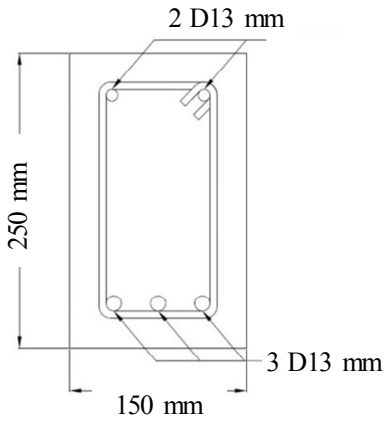

(b)

Fig. 1. Experimental set-up of OPS RC beam specimen (a) Experimental set-up of OPS RC beam specimen (in $\mathrm{cm}$ ), (b) Detail of section (in $\mathrm{mm}$ ). 
With the capacity of loading up to 12 tonnes, the hydraulic actuator loading application was distributed into two points of loading within $0.9 \mathrm{~m}$ leading to a four-point bending test. The step of the loading test was maintained at $200 \mathrm{~kg}$ for each beam. For measurement, five LVDT extensometers were employed to measure the displacement in the vertical direction at point 1, 2, 3, 4, and 5, as shown in Fig. 1. Furthermore, two strain gauges were attached to the steel reinforcing bar around the area identified a number 3, on the tension and compression bars.

\section{Results and discussion}

\subsection{Global behaviour: Force-vertical displacement}

Global behavior results of the RC beams under four-point loading are presented in the loading application (force) of the hydraulic jack in a function of vertical displacement at mid-span of the beam (measured by LVDT No. 3) curve as shown below in Fig. 2. Blue and red colors represent the behavior of beam number 1 and 2, respectively.

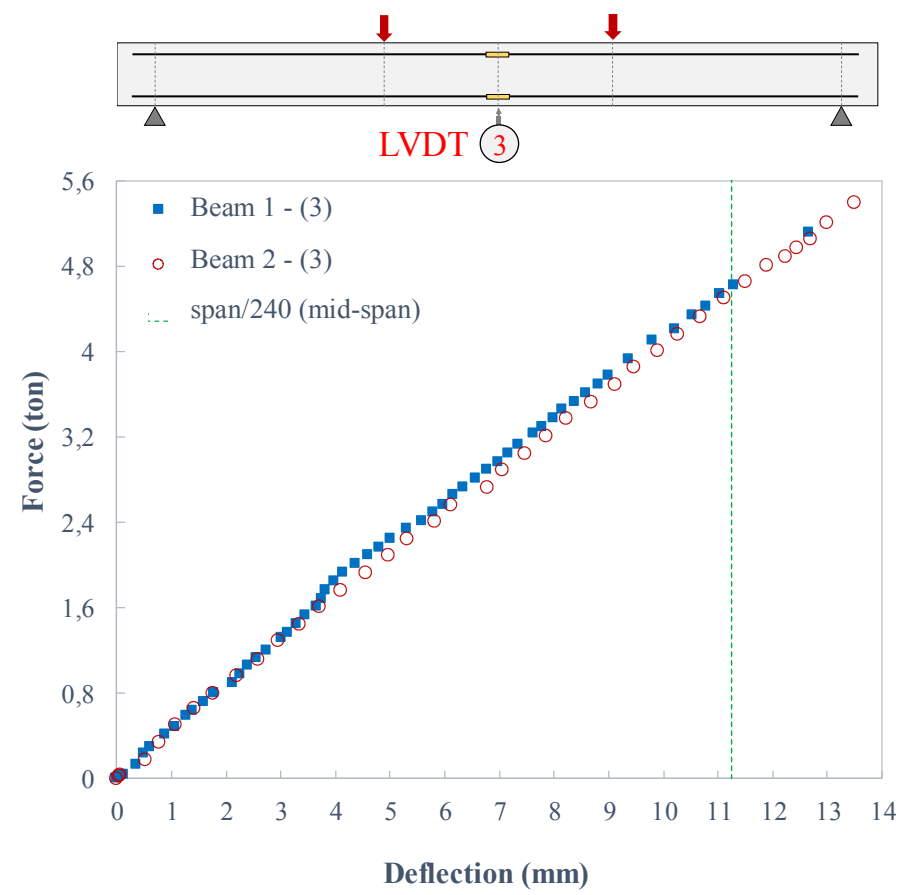

Fig. 2. Force - Displacement curve at mid-span (LVDT 3).

At around 2 tonnes of loading application, the stiffness of the beam changes; this indicates the first significant deformation on the beam. The stiffness of both beams are the same more or less up to the limit of the yielding point. The green line in the curve shows the allowable limit of deflection of the beam at service limit condition (1/240) according to [11]. It means that, at around 4.6 tonnes, both beams reached their service limit condition.

Deflections measured in other points of measurement (LVD No. 1, 2, 4, and 5) are presented in Fig. 3. The tendencies for both beams are the same. LVDT 1 and 5 have identical results, and the same condition is seen for LVDT 2 and 4 as the locations are relatively the same from both ends. LVDT 2 and 4 (one-third point from two ends) reached the limit of service deflection at around 5.06 tonnes of loading application. 


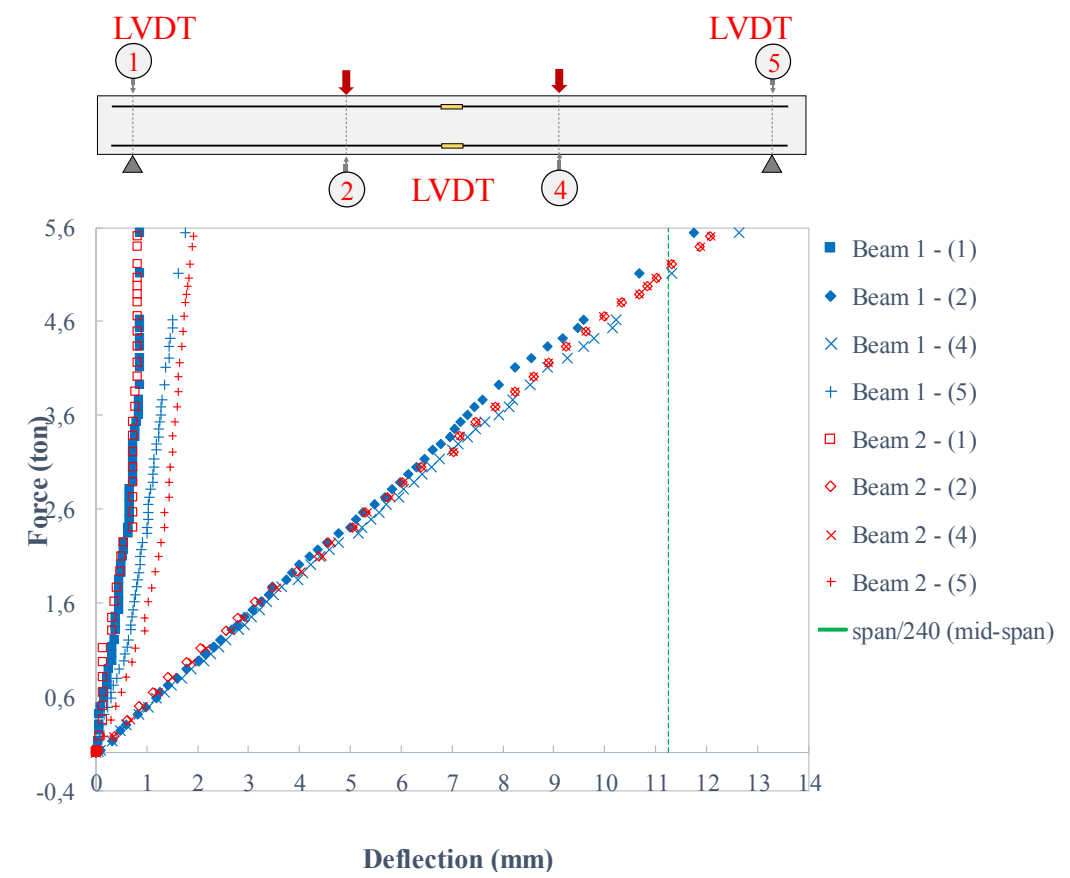

Fig. 3. Force - Displacement curve at LVDT 1, 2, 4, and 5.

\subsection{Beam at the end of the test}

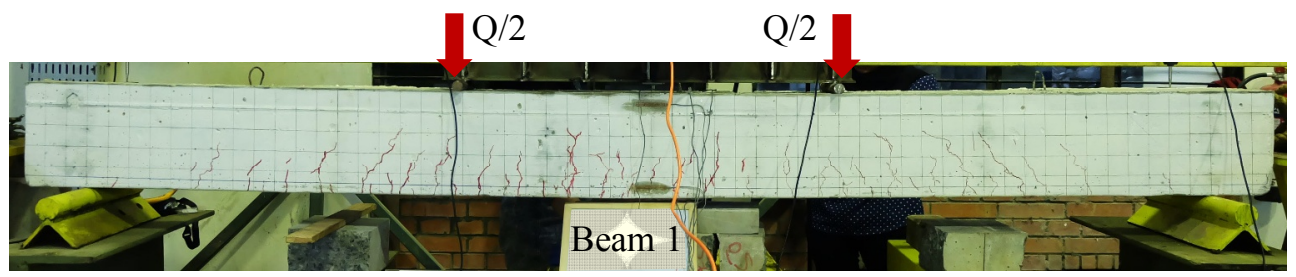

(a)

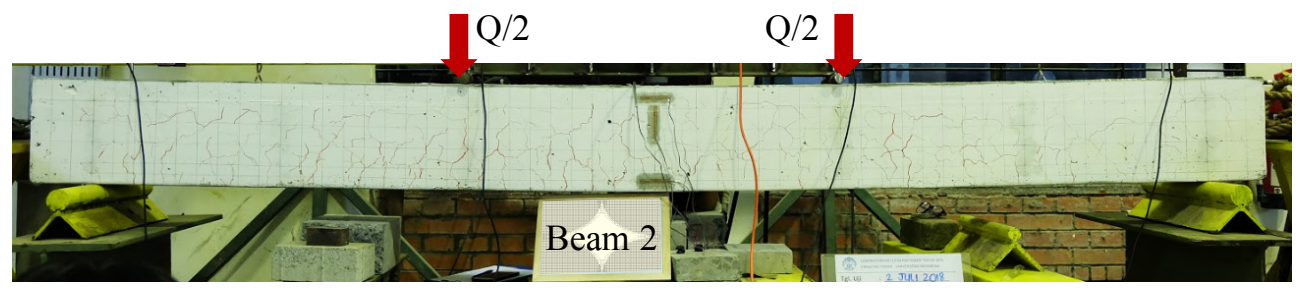

(b)

Fig. 4. Condition of the two beams at the end of the test (a) Beam 1 at the end of the test, (b) Beam 2.

Cracking pattern and deflection of the two beams at the end of the tests are presented in Fig. 4. During the experiment, after the first loading step application, several cracks spread on the two vertical surfaces of beam 2, which may signify shrinkage-induced cracks. Nevertheless, the force-displacement evolution presented in Fig. 2 and 3 show the same tendency for the two beams. The deflections of the two beams are more or less at the same value. At the end of elastic limit states, spall off concrete did not occur on either beam. 


\subsection{Strain measurement of steel bar reinforcements}

The objective of measuring the strain on the longitudinal steel bar is to find the behavior of the bar as to whether it reaches the yielding point or not during the test. Steel strain was measured with strain gauges attached to the tension steel bar. Acquisition system was set to measure the strain once every second. The stress-strain curve on steel bar for both samples are presented in Fig. 5. From this curve, it can be seen that the deformation of beam 2 is larger than the deformation of beam 1. It strengthens the previous arguments about the shrinkage deformation of beam 2. By taking $200 \mathrm{GPa}$ as its Young's modulus of elasticity, according to yield strength in Table 3, we obtain $2096.4 \mu \mathrm{m} / \mathrm{m}$ of strain. So, according to Fig. 5, the steel reinforcing bar of beam 2 is possibly tensioned until it reached its limit of elastic. It should be noted that the stress in Fig. 5 described inordinate is obtained from theoretical calculation of the stress from the flexural moment (from experimental loading application) divided by the second moment of area of the beam without cracks.

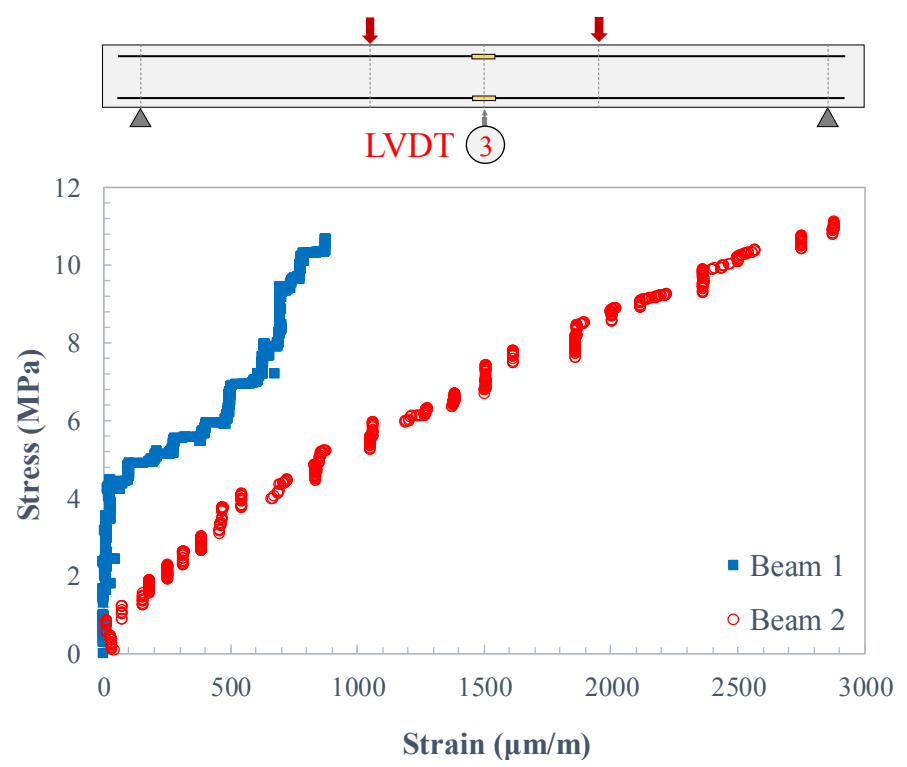

Fig. 5. Stress-strain curve of steel bar on the bottom of RC beam.

The lightweight concrete beam was designed by using a theoretical approach applied to normal concrete (concrete with natural coarse aggregates). At ultimate condition, theoretical maximum loading application is 5.9 tonnes. In this research, loading application is done up to the strain softening limit point of the beam, which is 5.06 tonnes (average from two beams). The service limit condition chosen according to the standard [11] is the maximum deflection of the beam at span over 240 . We obtain $11.25 \mathrm{~mm}$ as presented in the green dash line in Fig. 2. Therefore, the allowable limit of deflection of the beam at service is around 4.6 tonnes which are $78 \%$ of the ultimate theoretical load.

\section{Conclusions}

All beams showed typical behavior in flexure. Both beams have more or less the same point of elastic limit states. The main objective of this research is to understand the behavior of OPS RC beam as to whether it is suitable or not to be applied as a large structural element for simple structure. The rough calculation for simple housing standard based on [13] and [14] shows that the 4.6 tonnes of beam capacity in bearing the charge is strong enough to be 
used as a structural member for a two-story house building. At service limit condition, OPS $\mathrm{RC}$ beam can bear up to 4.6 tonnes. This means that further research on other elements of the structure may be performed to understand better the behavior of OPS RC structure, such as one-way slabs, columns, etc. Shrinkage during the curing process needs to be prevented since its effect is very significant in the second beam. Also, bond behavior is observed well during the test of the RC beam. Shrinkage and bond behavior in OPS concrete is interesting to be studied further for future works.

This work is supported by Hibah PITTA 2018 funded by DRPM Universitas Indonesia No.2428/UN2.R3.1/HKP.05.00/2018.

\section{References}

1. Directorate General of Estate Crops, Tree crop estate statistics of indonesia 2015-2017 palm oil (Ministry of Agriculture, Jakarta, 2016)

2. C.Y. May. Malaysia: Economic transformation advances palm oil industry. Available at: $\quad$ https://www.aocs.org/stay-informed/read-inform/featured-articles/malaysiaeconomic-transformation-advances-oil-palm-industry-september-2012 (2012)

3. H. Febriansyah, A.A. Setiawan, K. Suryopratomo, A. Setiawan, Energy Proc. 47 (2014)

4. E. Tjahjono, A.M. Fani, D.D. Dodi, E.P. Purnamasari, F. Silaban, E. Arijoeni, Mat. and Sci. Forum 902 (2017)

5. M.K. Yew, H.B. Mahmud, B.C. Ang, M.C. Yew, The Scientific World J. 2014 (2014)

6. M. Fani, Study of material characteristic on lightweight Oil Palm Shell (OPS) concrete using additives $1.2 \%$ of super plasticizer and silica fume (Universitas Indonesia, Depok, 2016)

7. F.A. Silaban, Study of material characteristic on lightweight Oil Palm Shell (OPS) concrete using additives 5.0\% of fly ash and super plasticizer (Universitas Indonesia, Depok, 2016)

8. E.P. Purnamasari, Study of material characteristic on lightweight oil palm shell (OPS) concrete using additives $5.0 \%$ of silica fume and super plasticizer (Universitas Indonesia, Depok, 2016)

9. D.D. Dodi, Study of material characteristic on lightweight Oil Palm Shell (OPS) concrete using additives 1.2\% of super plasticizer and fly ash (Universitas Indonesia, Depok, 2016)

10. S.T. Lee, Study on The effect of pre-treatment of oil palm shell as coarse aggregate using hot water $50^{\circ} \mathrm{C}$ and common water $28^{\circ} \mathrm{C}$ to lightweight concrete strength (Universitas Indonesia, Depok, 2016)

11. Standar Nasional Indonesia, Persyaratan Beton Struktural untuk Bangunan Gedung SNI 2847-2013 (Badan Standardisasi Nasional, Jakarta, 2013)

12. Standar Nasional Indonesia, Metode Pengujian Kuat Tarik Baja Beton SNI 07-25291991 (Badan Standardisasi Nasional, Jakarta, 1991)

13. Standar Nasional Indonesia, Beban Minimum Untuk Perancangan Bangunan Gedung Dan Struktur Lain SNI 1727-2013 (Badan Standardisasi Nasional, Jakarta, 2013)

14. Standar Konstruksi Bangunan Indonesia, Pedoman Perencanaan Pembebanan Untuk Rumah dan Gedung SKBI-1.3.53.1987 (Departemen Pekerjaan Umum, Jakarta, 1987) 